\title{
Fungal Taxol Extracted from Cladosporium oxysporum Induces Apoptosis in T47D Human Breast Cancer Cell Line
}

\author{
Kathamuthu Gokul Raj ${ }^{1}$, Shanmugam Sambantham², Ramar Manikanadan ${ }^{3}$, \\ Chinnansamy Arulvasu ${ }^{3}$, Mohan Pandi ${ }^{*} *$
}

\begin{abstract}
Purpose: The present study concerns molecular mechanisms involved in induction of apoptosis by a fungal taxol extracted from the fungus Cladosporium oxysporum in T47D human breast cancer cells. Materials and Methods: Apoptosis-induced by the fungal taxol was assessed by MTT assay, nuclear staining, DNA fragmentation, flow cytometry and pro- as well as anti-apoptotic protein expression by Western blotting. Results: Our results showed inhibition of T47D cell proliferation with an $\mathrm{IC}_{50}$ value of $2.5 \mu \mathrm{M} / \mathrm{ml}$ after $24 \mathrm{~h}$ incubation. It was suggested that the extract may exert its anti-proliferative effect on human breast cancer cell line by suppressing growth, arresting through the cell cycle, increase in DNA fragmentation as well as down-regulation of the expression of NF-kB, Bcl-2 and Bcl-XL and up-regulation of pro-apoptotic proteins like Bax, cyt-C and caspase-3. Conclusions: We propose that the fungal taxol contributes to growth inhibition in the human breast cancer cell through apoptosis induction via a mitochondrial mediated pathway, with possible potential as an anticancer therapeutic agent.
\end{abstract}

Keywords: Fungal taxol - apoptosis - DNA fragmentation - DNA damage - NF-kB

Asian Pac J Cancer Prev, 15 (16), 6627-6632

\section{Introduction}

Cancer is caused by unregulated cell proliferation and it is the leading cause of death both in developed and in developing countries, about 12.7 million new cases and 7.6 million cancer associated deaths were estimated worldwide (Jemal et al., 2011). Breast cancer is the fourth major widespread malignancy globally (Zhang et al., 2014). Present treatment strategies such as surgical excision, immunotherapy and radiotherapy stay highly palliative for breast and other cancer patients because the disease recurs in a refractory form and quality of life has been highly exaggerated due to severe side effects (American cancer society). The effective chemotherapeutic drugs including gleevec (imatinib mesylate), taxol (Paclitaxel), herceptin (trastuzumab), vinblastine (Velbe) and Iressa (gefitinib) can be used between control and malignant cells to selectively induce apoptosis in cancer cells (Chang et al., 2004; Mohsin et al., 2005).

Apoptosis is a programmed cell death (PCD) which plays an essential role in cell survival of the organisms by inhibiting only tumor cells. Mechanism of apoptosis is to kill the cells specifically without leaking and inflammation but involves in biochemical and physical changes like inter nucleosomal degradation of DNA, condensation of nuclei and blebbing of plasma membrane (Elmore,
2007). Besides a considerable part of the profits also been achieved by chemotherapy which depends on the activation of apoptosis in cancer cells. In tumor cells antiapoptotic proteins have been highly expressed and it is recognized as a key target point of anti-cancer therapeutic interventions (Varol et al., 2014) and their inhibitors at the levels of proteins and mRNA is developed (Yang et al., 2008). One of the major executioners of apoptosis is a set of cysteine proteases called caspases that are initially synthesized as inactive zymogens called procaspases.

Due to high cost and increased side effects of commercially available drugs, diverse medicinal plants represent vast potential sources are habitually used for treatment of cancer (Bachrach, 2012). The endophytic fungus which produces taxol (paclitaxel), a tubulinbinding diterpenoid, first isolated from Taxus brevifolia used in the treatment of different cancers in-vitro (Wani et al., 1971; Schiff et al., 1979). It specifically binds to the $\beta$-tubulin subunit of microtubules and crumple their dynamic instability and thereby prevents the function of normal cell cycle at the G2/M phase, ultimately which leads to cell death by apoptosis (Orr et al., 2003). The compound isolated from different endophytic fungi posse's anti-cancer effects on different cancer cell lines and also it has been ability to inhibit DMBA- induced mammary carcinoma in rats (Kumaran et al., 2009; Vennila et al., 
2010; Pandi et al., 2011).Only very few studies is currently available on the mechanism of underlying stimulation of apoptosis by fungal taxol. The present study is aimed to detect the anti-cancer efficacy of fungal taxol using T47D breast cell line by in-vitro assays.

\section{Materials and Methods}

\section{Cell line and culturing}

Breast cancer cell line T47D was obtained from National Centre for Cell Science (NCCS), Pune, India. The experiments were carried out on T47D cell line cultured in Dulbecco's modified Eagle medium (DMEM, Gibco) supplemented with $10 \%$ heat- inactivated fetal bovine serum (FBS, Gibco), $2 \mathrm{mM}$ glutamine and $1 \%$ antibiotics (penicillin/streptomycin/ fungizone (10, 000 units $/ \mathrm{ml}, 10,000 \mu \mathrm{g} / \mathrm{ml}, 25 \mu \mathrm{g} / \mathrm{ml})$. Cells were grown as monolayer in tissue culture flasks in humidified atmosphere under the conditions of $37^{\circ} \mathrm{C}$ with $5 \% \mathrm{CO}_{2}$ gas in the $\mathrm{CO}_{2}$ incubator.

\section{Cytotoxity evaluation by MTT assay}

Cytotoxicity effect was determined by MTT (3- (4, 5-dimethylthiazolyl-2)-2, 5-diphenyltetrazolium bromide) assay (Van de Loosdrecht et al., 1994; Mosmann et al., 1983). Briefly, cells were seeded into 96 well plates approximately $2 \times 10^{4}$ cells per well. The cells were treated with or without fungal taxol at different concentrations (1-10 $\mu \mathrm{M})$ for $24 \mathrm{~h}$. Then, $10 \mu \mathrm{l}$ of MTT $(5 \mathrm{mg} / \mathrm{ml})$ was added in each well and incubated for $4 \mathrm{~h}$. The purple colour formazone crystals formed were dissolved in 100 $\mu \mathrm{l}$ of DMSO and observed at $570 \mathrm{~nm}$ using an ELISA plate reader (Synergy HT Multi-Mode Microplate Reader BioTek, USA). Optical density value was converted to percentage of viability by using the following formula: Percentage of growth inhibition $=($ A570 of treated cells $/$ A570 of control cells) $\times 100$.

\section{Cell and nuclear morphology assessment}

The cells were seeded at $2 \times 10^{4}$ cell/well into a six well chamber plate and incubated overnight. Later, the medium was replaced with maintenance medium DMEM without FBS containing $2.5 \mu \mathrm{M}$ and $10 \mu \mathrm{M}$ fungal taxol incubated for $24 \mathrm{~h}$. The cell morphology was examined under Nikon inverted microscope. Moreover, the treated cells were fixed with ice-cold $4 \%$ para-formaldehyde for $10 \mathrm{~min}$ and washed with ice-cold PBS, then permeabilized with $0.25 \%$ Triton X-100 and stained with fluorochrome dye 4, 6-diamidino-2-pheylindole (DAPI, Santa Cruz, USA). The cells were observed under a fluorescence microscope (Nikon Eclipse-80i, Japan) with a peak excitation wavelength of $340 \mathrm{~nm}$.

\section{DNA fragmentation assay}

$5 \times 10^{4}$ exponentially growing cell of T47D were seeded onto 6 well plates for $24 \mathrm{~h}$ followed by treatment with $\mathrm{IC}_{50}$ concentration of the fungal taxol. For analysis of genomic DNA, cell were harvested and collected together along with non attached cells. The cells were shaken and cleared by centrifugation at $13,000 \times \mathrm{g}$ for $10 \mathrm{~min}$. Cells were resuspended in $0.5 \mathrm{ml}$ of lysis buffer $(50 \mathrm{mM}$ Tris- $\mathrm{HCl}$,
$100 \mathrm{mM}$ EDTA, $0.5 \%$ sodium dodecyl sulfate ( $\mathrm{pH}$ 8.0) containing $0.1 \mathrm{mg} / \mathrm{ml}$ RNase A. After incubation at $37^{\circ} \mathrm{C}$ for $30 \mathrm{~min}$, cells were extracted with phenol/chloroform, iso-amyl alcohol and precipitated with ethanol. DNA pellets were dissolved in $20 \mu \mathrm{l}$ of TE buffer. DNA samples were separated by electrophoresis on a $1.5 \%$ agarose gel. The gel was stained with ethidium bromide, visualized under UV light, and photographed.

\section{Analysis of apoptosis by flow cytometry}

For cell cycle analysis, $1 \times 10^{6}$ cells $/ \mathrm{ml}$ was treated with fungal taxol in the presence or absence at 2.5 and $10 \mu \mathrm{M}$ doses. After $24 \mathrm{~h}$ incubation, the cells were washed with $1 \times$ PBS and fixed with chilled $80 \%$ ethanol and kept for 2 $\mathrm{h}$ at $4^{\circ} \mathrm{C}$. Prior to stain with $50 \mu \mathrm{g} / \mathrm{ml}$ propidium iodide, the cells were incubated for $1 \mathrm{~h}$ with $100 \mu \mathrm{g} / \mathrm{ml}$ of DNAse free RNAse A at $37^{\circ} \mathrm{C}$. The cell cycle was analyzed with a FACS Diva Version 6.1.3 flow cytometer.

\section{Western blots}

After $24 \mathrm{~h}$ incubation, the cells are lysed using RIPA buffer containing $1 \mathrm{X}$ protease inhibitor cocktail (Sigma Aldrich, USA). The protein concentrations were calculated using Lowry's method (Lowry et al., 1951). Cell lysates $(20-50 \mu \mathrm{g})$ were electrophoresed in $12 \%$ SDS polyacrylamide gel and then transferred to PVDF membranes (Millipore). The membranes were incubated with primary antibodies against $\mathrm{Bax}, \mathrm{Bcl}-2$, Bcl-XL, cytochrome c (1:2000 caspase -3, NF-kB and GAPDH (1:1000) (Santa Cruz, USA) in Tris-buffered saline. The membranes were washed and incubated with HRP-conjugated goat-anti mouse IgG (1:5000) and HRPconjugated goat-anti rabbit IgG (1:5000) accordingly. Protein bands were detected using chemi-luminescence system (Rapid ECL detection kit, Merck, USA) and quantified using Chemi Doc XRS Imaging System, Bio$\operatorname{Rad}(U S A)$.

\section{Results}

\section{MTT assay}

Human breast cancer T47D cells were cultured in the absence and presence of fungal taxol at various concentrations. As shown in (Figure 1), cell viability decreased systematically with increased concentration as well as time dependent of fungal taxol compared with control for the same exposure time. The inhibitory rates for cells treated with different concentrations of fungal

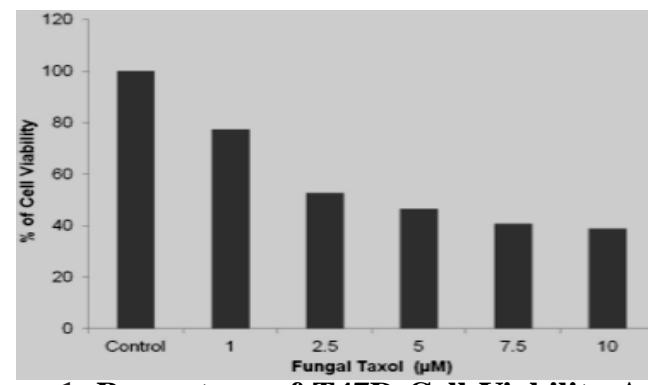

Figure 1. Percentage of T47D Cell Viability Against

Fungal Taxol. The $\mathrm{IC}_{50}$ value is the concentration required for $50 \%$ growth inhibition. Cell proliferation was determined at $24 \mathrm{~h}$ 

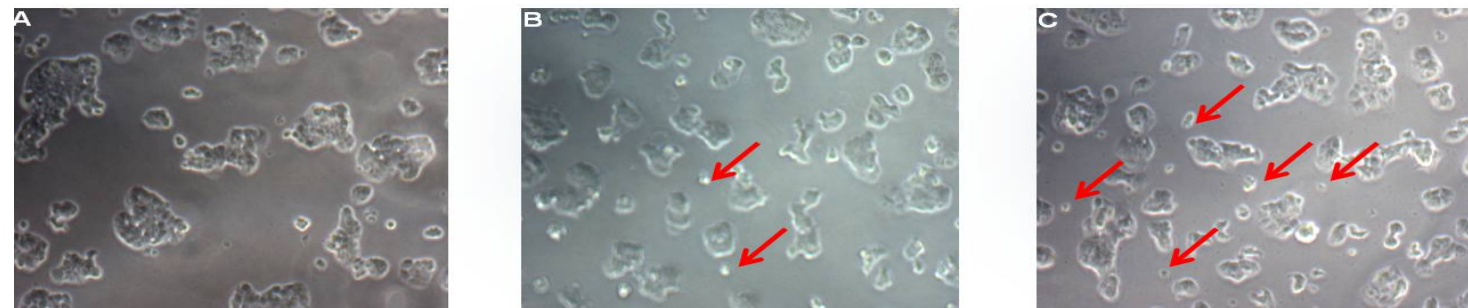

Figure 2. Cytomorphology assessment. (A) Control T47D cells (B) and (C) T47D Cells treated with $\mathrm{IC}_{50}$ of fungal taxol at 24 h (Magnification 40x)
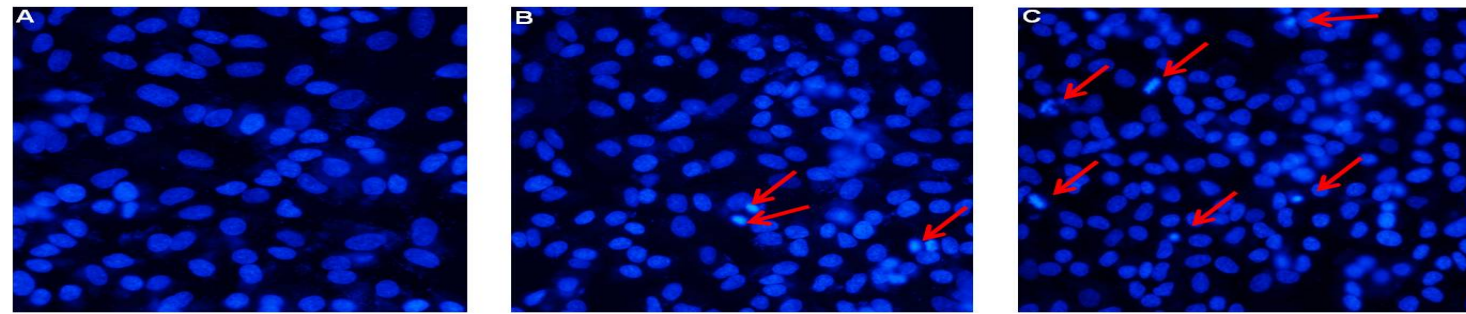

Figure 3. Nuclear Morphology Assessment by Fluorescence Staining. (A) Control T47D cells (B and C) Nuclear morphology assessment of T47D cells using DAPI staining (Magnification 100x)

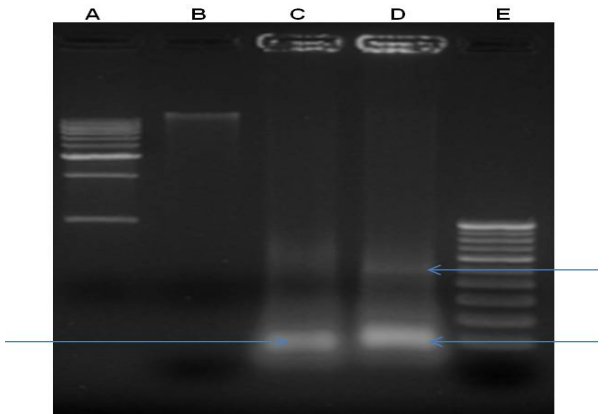

Figure 4. DNA Fragmentation (arrows) of T47D cells treated with fungal taxol. From left to right; lane (A) $1 \mathrm{~kb}$ DNA ladder (B) untreated T47D cells (C) and (D) Cells treated with fungal taxol after $24 \mathrm{~h}$ respectively (E) $100 \mathrm{bp}$ DNA ladder.

taxol $(1-10 \mu \mathrm{M})$ with a calculated $\mathrm{IC}_{50}$ of $2.5 \mu \mathrm{M}(24$ $\mathrm{h}$ treatment). Results showed that fungal taxol could significantly inhibit the viability of the cancer cells and have potential anticancer activity.

\section{Cell morphology assessment}

Microscopic observations were monitored using Nikon light inverted microscope wherein treated cell showed cellular morphology changes indicating unhealthy cells, whereas the control appeared normal (Figure 2). Control cells were irregular, aggregates with rounded and polygonal cells. Fungal taxol treated cells appeared to shrink, became spherical in shape and cell spreading patterns were restricted when compared to control.

The nuclei changes in T47D cells were observed under a fluorescent microscope. As shown in (Figure 3) control cells emitted a blue fluorescence with consistent intensity, indicating that the chromatin was equivalently distributed in the nuclei. Following incubation with fungal taxol, the cells displayed chromatin congregated and karyopynosis, which emitting bright fluorescence.

\section{DNA fragmentation assay}

In fragmentation, untreated cells only contain the higher molecular weight genomic DNA. The addition
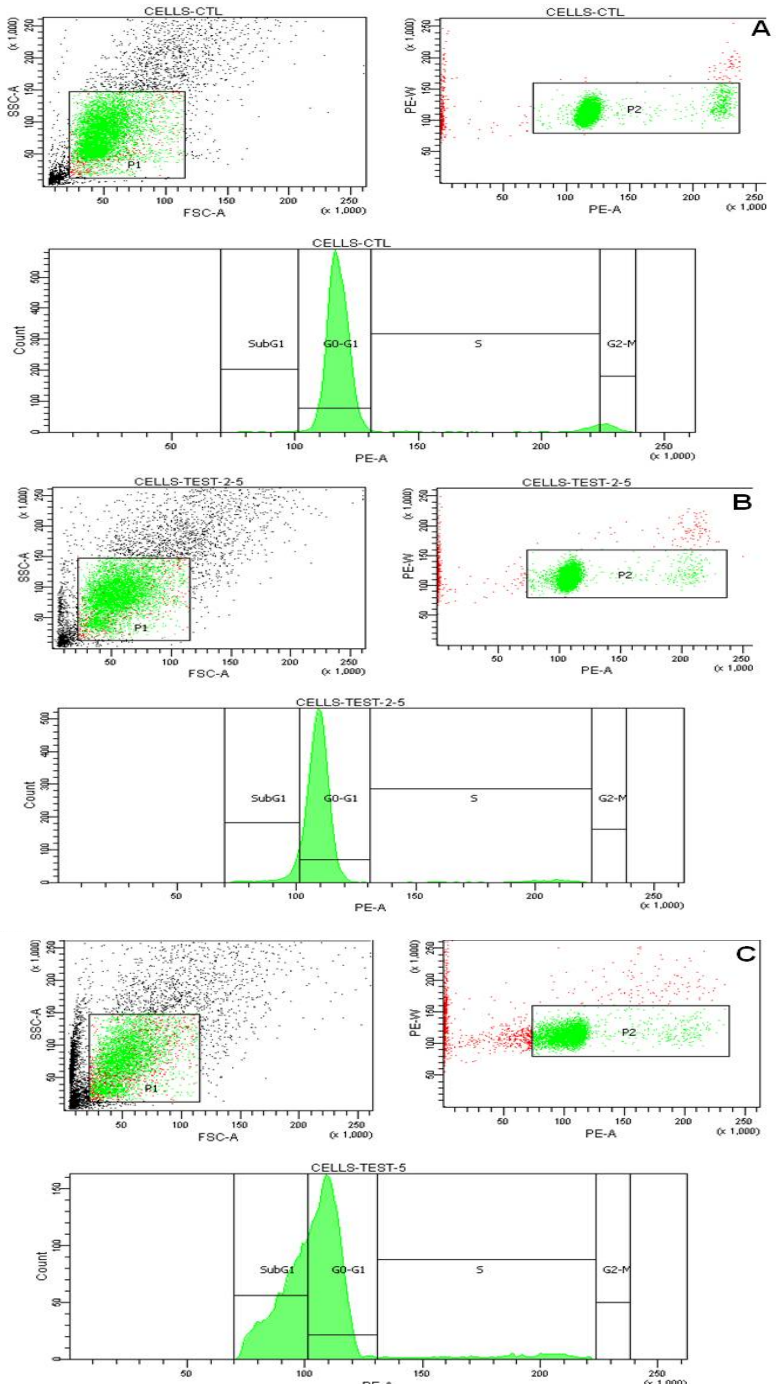

Figure 5. Flow Cytometry Analysis of T47D Cells. (A) Control (B) and (C) T47D Cells Treated with Fungal Taxol

of fungal taxol showed the distinguishing pattern of nucleosomal degradation precise to apoptosis which was visualized in faint bands on the agarose gel. DNA fragments produce of low molecular weight consisting 


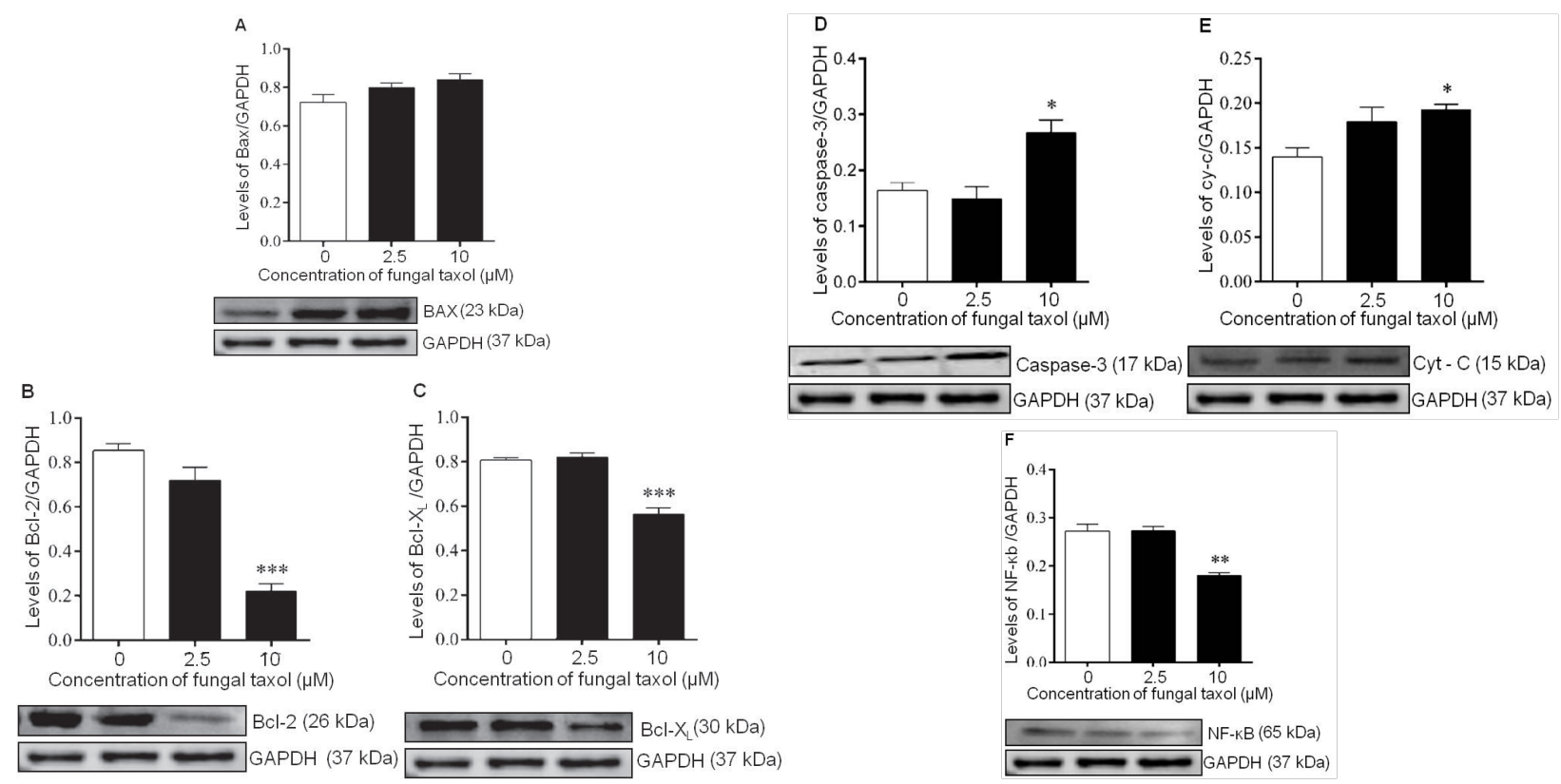

Figure 6. Western Blot Analysis of Control and Treated Cell. (A) Bax; (B) and (C) Bcl-2, Bcl-XL; (D) and (E) Caspase-3, Cytochrome-c and (F) NF-kB expression normalized with GAPDH. '**', ‘***' and '*' represents statistical significance between control $v s$ fungal taxol treated groups

of multimers of 100 and $600 \mathrm{bp}$ on T47D cell line respectively. The results showed that the fungal taxol was able to induce apoptosis in T47D cells (Figure 4).

\section{Apoptosis by flow cytometry}

The results indicate T47D cells undergoing apoptosis after treatment with anticancer drug fungal taxol. As the percentage of drug increases, the percentage of apoptotic cells increases indicating that the drug induces apoptosis is dose dependent manner. The drug also induces G1 arrest but since apoptosis induction is more prominent the arrested population is not visible as distinct G1 population and instead sub G1 population is more (Figure 5).

\section{Western blot analysis}

The western blot analysis also showed similar trend in all the protein analysed. Pro- apoptotic protein Bax showed higher level expression (Figure 6A), whereas the anti-apoptotic proteins such as Bcl-2 and Bcl-XL showed decreased protein expression (Figure 6B, C). Caspase-3 and cytochrome-c has also shown the elevated level of protein expression in treated cells when compared to control cells (Figure 6D, E). Moreover, the protein level of NF-kB was decreased when treated with fungal taxol (Figure 6F). All the data are normalised with GAPDH housing keeping gene which was used as a control.

\section{Discussion}

The majority of breast cancer cells turn out to be resistant against chemotherapeutic drugs due to mutation happen in apoptotic mechanisms (Merlin et al., 2010). Taxol continues to have an increasing role in the treatment of human malignancies, particularly ovarian and breast cancer (DeVita et al., 1997). Taxol shows the efficacy of fungal taxol against human breast cancer cell (T47D) viability via apoptosis. The decrease in viability after taxol inclusion was assessed by MTT where it is reduced to purple formazan in the mitochondria of living cells can be measured using spectrophotometer at a wavelength between 500 and $600 \mathrm{~nm}$ (Van de Loosdrecht et al., 1994) Our challenge here was to study the anticancer effect of fungal taxol on human breast cancer cell line in-vitro and investigate the mechanism accordingly. As such, our data demonstrate the fungal taxol is efficacious against human breast cancer cell line with $\mathrm{IC}_{50}$ values in the of 2.5 to $10 \mu \mathrm{M}$, decreased systematically with increased concentration as well as time dependent of fungal taxol compared with controls for the same exposure time which was similar to our report (Yeung et al., 1999; Kumaran et al., 2009; Pandi et al., 2011).

In addition induction of apoptosis is one important mechanism by which an anticancer agent acts. As such, inadequate apoptosis is an integral part of cancer development can be observed through unique morphological attribute using phase contrast and fluorescence microscopy (Xu et al., 2007; Doonan and Cotter 2008). Many anticancer drugs have been shown to cause the death of sensitive cells through the induction of apoptosis (Cai et al., 2006). Our data shows that human breast cancer cell line T47D cells treated with fungal taxol displayed typical apoptotic phenomena with chromatin condensation and karyopyknosis. Apoptosis is a type of cell death process regulated in an orderly way by a series of signal cascades under certain situations (Majno and Joris, 1995).

Cellular response to DNA damage is the important mechanism of inhibiting DNA synthesis. The damage of DNA observed in agarose gel electrophoresis after induced with taxol. A multiple fragment DNA ladder like pattern formation was observed oligonuleosomal cleavage (100$600 \mathrm{bp}$ ) where as internucleosomal cleavage of DNA is likely to form in later phase of apoptotic progression. This pattern of distinct DNA ladder is considered to be 
Fungal Taxol Extracted from Cladosporium oxysporum Induces Apoptosis in T47D Human Breast Cancer Cells

a biochemical characteristic of apoptosis (Cohen, 1993). Similar anomalies had been observed earlier (Kajimoto et al., 2002; Alabsi et al., 2013).

The cells undergoing apoptosis, DNA was fragmented to low molecular weight and subsequently leaked out from cells and DNA content were stained with a specific DNA fluoro-chrome propidium iodide (PI), a special DNA peak (generally called sub G1 peak) obtained. The G0/G1 population of fungal taxol treated T47D cells was increased after $24 \mathrm{hrs}$ incubation. Our analysis have embedded prominent increase in the sub G0 DNA upon treated with fungal taxol is an indication of the inhibition of DNA replication. Less number of cells in the G2-M phase also confirms the same. The possible mechanism would be the down regulation in the activity of cell cycle proteins (Cycle E dependent kinase). Due to this cell cycle progression at the G1-S phase transition stage has been reduced, possibly some of the key cell cycle regulator genes such as p21 and their upstream molecule p51 functions have been altered. Some of the earlier reports have also described the hallmark mechanism of apoptosis detection (Kathiravan et al., 2010; Li et al., 2014).

In addition, western blot analysis reveals the expression levels of several anti-apoptotic and proapoptotic proteins associated to apoptosis which occurs either through extrinsic or intrinsic pathway. In intrinsic pathway, DNA damage leads to the phosphorylation of p53 which further pro-apoptotic proteins are tanscriptionally activated (Roos and Kaina 2006). Anti-apoptotic proteins over expressed in tumour cells have been renowned as striking targets for anti-cancer therapeutic intervention (Arkin, 2005). In our analysis, after fungal taxol treatment Bax were up-regulated which leads to oligomerization and permeablization of the mitochondrial membrane by rupturing or development of precise channels in the membrane (Bleicken et al., 2010).

Due to this action cytochrome-c has released from mitochondria ultimately resulting in the activation of caspase cascade (Chen et al., 2005; Liu and Huang, 2011). Correspondingly in our analysis, cytochrome-c has shown increased expression as well as executioner caspase- 3 involved in the present study at pivotal junctions in apoptosis pathway has been show elevated expression. Numerous studies indicate Bax is a trigger of cytochrome-c release (Eskes et al., 1998; Jurgensmeier et al., 1998; Rosee et al., 1998). Moreover, Bax gene acts as a direct transcriptional target of p53 a tumor suppressor protein, signifying an important role of Bax in radio- chemo responses of tumors. The mitochondrial pathway controlled by group of Bcl-2 family of proteins, higher expression of this protein prevents Bax function (Antonsson et al., 2001).

Normally higher expression of Bcl-2 and Bcl-XL has been pragmatic in several types of cancer (Antosiewicz and Singh 2004). The decrease in the significant expression of anti-apoptotic proteins such as Bcl-2 and Bcl-XL was observed along with NF-kB when treated with fungal taxol resulting in mitochondria-mediated apoptosis in T47D cell line. Generally NF-kB is residing in the cytoplasm, once activated by various signals translocated into the nucleus and regulates the expression of both anti-apoptotic and pro-apoptotic genes. Recently some of the target genes activated by NF-kB (cyclin D1, Bcl-2, Bcl-XL, matrix metallo-proteinases (MMPs) and VEGF) which are very important for cellular transformation, cell proliferation, invasion, migration and metastasis (Sambantham et al., 2013). The other report explains either up-regulation of Bax or decrease in the Bcl-2 protein level after treatment with various cancer drugs resulting in mitochondrial mediated apoptosis (Wan et al., 2013). Together, the present results have demonstrated that fungal taxol could inhibit breast cancer cell line through regulation of various apoptotic signalling proteins.

\section{Acknowledgements}

The authors (Dr. M. Pandi and K. Gokul Raj) thank University Grants Commission (UGC) F.No.39-207/2010 (SR), Delhi for financial support and Madurai Kamaraj University Madurai, Tamil Nadu, India for providing the laboratory facilities".

\section{References}

Alabsi AM, Ali R, Ali Am, et al (2013). Induction of caspase-9, biochemical assessment and morphological changes caused by apoptosis in cancer cells treated with Goniothalamin extracted from Goniothalamus macrophyllus. Asian J cancer Pre, 14, 6273-80.

American Cancer Society. Breast cancer facts and figures 20112012. Atlanta: American cancer society, Inc.

Antonsson B, Montessuit S, Sanchez B, Martinou JC (2001). $\mathrm{Bax}$ is present as a high molecular weight oligomer/complex in the mitochondrial membrane of apoptotic cells. J Biol Chem, 276, 11615-23.

Antosiewicz HA, Singh SV (2004). Signal transduction pathways leading to cell cycle arrest and apoptosis induction in cancer cells by allium vegetable-derived organosulfur compounds: a review. Mutat Res, 555, 121-31.

Arkin M (2005). Protein-protein interactions and cancer: small molecules going in for the kill. Curr Opin Chem Biol, 9, 317-24.

BachrachYZ (2012).Contribution of selected medicinal plants for cancer prevention and therapy. Scientific J Faculty of Medicine Nis, 29, 117-23.

Cai SX, Drewe J, Kasibhatla S (2006). A chemical genetics approach for the discovery of apoptosis inducers: from phenotypic cell based hts assay and structure-activity relationship studies, to identification of potential anticancer agents and molecular targets. Curr Med Chem, 13, 2627-44.

Chang GC, Hsu SL, Tsai JR, et al (2004). Molecular mechanisms of ZD1839-induced G1-cell cycle arrest and apoptosis in human lung adenocarcinoma A549 cells. Biochem Pharmacol, 68, 1453-64.

Chen WY, Wu CC, Lan YH, et al (2005). Goniothalamin induces cell cycle-specific apoptosis by modulating the redox status in MDA-MB-231 cells. Eur J Pharmacol, 522, 20-9.

Cohen JJ (1993). Apoptosis: the physiologic pathway of cell death. Hosp Pract, 28, 35-43.

DeVita VT Jr, Hellman S, Rosenberg SA (1997). Cancer. Principles and practice of oncology. Philadelphia, PA: Lippincott-Raven Publishers, 5th edn. pp. 103-119.

Doonan F, Cotter XM (2008). Morphological assessment of apoptosis. Methods, 200-4.

Elmore S (2007). Apoptosis: a review of programmed cell death. Toxicol Pathol, 35, 495-516. 


\section{Kathamuthu Gokul Raj et al}

Eskes R, Antonsson B, Osen-Sand A, et al (1998). Bax-induced cytochrome $\mathrm{c}$ release from mitochondria is independent of the permeability transition pore but highly dependent on Mg2+ ions. J Cell Biol, 143, 217-24.

Jemal A, Bray F, Center MM, et al (2011). Global cancer statistics. CA Cancer J Clin, 61, 69-90.

Jurgensmeier JM, Xie Z, Deveraux Q, et al (1998). Bax directly induces release of cytochrome $\mathrm{c}$ from isolated mitochondria. Proc Natl Acad Sci USA, 95, 4997-5002.

Kajimoto S, Takanashi N, Kajimoto T, et al (2002) Sophoranone, extracted from a traditional Chinese medicine Shan Dou Gen, induces apoptosis in human leukemia U937 cells via formation of reactive oxygen species and opening of mitochondrial permeability transition pores. Int J Cancer, 99, 879-90.

Kathiravan G, Sureban SM (2010). Effect of taxol from Pestalotiopsis mangiferae on A549 cells in-vitro study. $J$ Basic and Clinical Pharmacy, 1, 1-8.

Kumaran RS, Muthumary J, Hur BK (2009) Isolation and identification of an anticancer drug, taxol from Phyllosticta tabernaemontanae, a leaf spot fungus of an angiosperm, Wrightia tinctoria. J Microbiol, 47, 40-9.

Li T, Xu WS, Wu GS, et al (2014). Platycodin D induces apoptosis, and inhibits adhesion, migration and invasion in HepG2 hepatocellular carcinoma cells. Asian Pac J Cancer Prev, 15, 1745-9.

Liu D, Huang Z (2011). Synthetic peptides and non-peptidic molecules as probes of structure and function of Bcl-2 family proteins and modulators of apoptosis. Apoptosis, 6, 453-62.

Lowry OH, Rosebrough NJ, Farr AL, Randall RY (1951). Protein measurement with the folin-phenol reagent. J Biol Chem, 193, 265-75.

Majno G, Joris I (1995). Apoptosis, Oncosis, and Necrosis An overview of cell death. Am J Pathol, 146, 3-15.

Merlin NJ, Parthasarathy V, Santhoshkumar TR (2010). Induction of apoptosis in human breast cancer cell line MCF-7 by phytochemicals from Gmelina asiatica. Afr J Biotechnol, 9, 4451-6.

Mohsin SK, Weiss HL, Gutierrez MC, et al (2005) Neoadjuvant trastuzumab induces apoptosis in primary breast cancers. $J$ Clin Oncol, 23, 2460-8.

Mosmann T (1983). Rapid colorimetric assay for cellular growth and survival: application to proliferation and cytotoxicity assays. J Immunol Methods, 65, 55-63.

Orr GA, Verdier-Pinard P, McDaid H, Horwitz SB (2003). Mechanisms of taxol resistance related to microtubules. Oncogene, 22, 7280-95.

Pandi M, Kumaran RS, Choi YK, Kim HJ, Muthumary J (2011) Isolation and detection of taxol, an anticancer drug produced from Lasiodiplodia theobromae, an endophytic fungus of the medicinal plant Morinda citrifolia. Afr J Biotechnol, 10, 1428-35.

Roos WP, Kaina B (2006). DNA damage-induced cell death by apoptosis. Trends Mol Med, 12, 440-50.

Rosse T, Olivier R, Monney L, Rager M, Conus S, Fellay I, Jansen B, Borner C (1998). Nature, 391, 496-9.

Sambantham S, Radha M, Paramasivam A, et al (2013). Molecular mechanism underlying hesperetin-induced apoptosis by in silico analysis and in prostate cancer PC-3 cells. Asian Pac J Cancer Prev, 14, 4347-52.

Schiff PB, Fant J, Horwitz SB (1979). Promotion of microtubules assembly in-vitro by taxol. Nature, 277, 665-7.

Steinhoff J, Classen M, Padmavathi PVL, Ishikawa T, Zeth K, Steinhoff HJ, Bordignon E (2010). Oligomerization, and membrane insertion molecular details of bax activation. $J$ Biol Chem. 285, 6636-47.

Van de Loosdrecht AA, Beelen RH, Ossenkoppele GJ,
Broekhoven MG, Langenhuijsen MM (1994). A tetrazoliumbased colorimetric MTT assay to quantitate human monocyte mediated cytotoxicity against leukemic cells from cell lines and patients with acute myeloid leukemia. J Immunol Methods, 174, 311-20.

Varol U, Yildiz I, Alacacioglu A, Uslu R (2014) Anticancer therapy for breast cancer patients with skin metastases refractory to conventional treatments. Asian Pac J Cancer Prev, 15, 1885-7.

Vennila R, Thirunavukkarasu SV, Muthumary J (2010) Evaluation of fungal taxol isolated from an endophytic fungus Pestalotiopsis pauciseta VM1 against experimentally induced breast cancer in sprague dawely rats. Res $J$ pharmacol, 4, 38-44.

Wan HF, Yu LH, Wu JL, et al (2013). Effect of diallyl trisulfide on human ovarian cancer SKOV- 3/DDP cell apoptosis. Asian Pac J Cancer Prev, 14, 7197-201.

Wani MC, Taylor HL, Wall ME, Coggon P, McPhail AT (1971). Plant antitumor agents VI: The isolation and structure of taxol, a novel antilekemic and antitumor agent from Taxus brevifolia. J Am Chem Soc, 93, 2325-27.

Xu ZX, Liang J, Haridas V, et al (2007). A plant triterpenoid, avicin $\mathrm{D}$, induces autophagy by activation of AMP-activated protein kinase. Cell Death Differ, 14, 1948-57.

Yang JK (2008). FLIP as an anti-cancer therapeutic target. Yonsei Med J, 49, 19-27.

Yeung TK, Germond C, Chen X, Wang Z (1999). The mode of action of taxol: Apoptosis at low concentration and necrosis at high concentration. Biochem Biophys Res Commun, 263, 398-404.

Zhang LL, Wu J, Liu Q, et al (2014). MiR-886-5p inhibition inhibits growth and induces apoptosis of MCF7 cells. Asian Pac J Cancer Prev, 15, 1511-5. 